\title{
Impact of climate change on human and animal health
}

Citation for published version (APA):

McIntyre, K. M., Setzkorn, C., Baylis, M., Waret-Szkuta, M., Caminade, C., Morse, A. P., Akin, S., Huynen, M., Martens, P., \& Morand, S. (2010). Impact of climate change on human and animal health. Veterinary Record, 167(15), 586-586. https://doi.org/10.1136/vr.c5523

Document status and date:

Published: 09/10/2010

DOI:

10.1136/vr.c5523

Document Version:

Publisher's PDF, also known as Version of record

Document license:

Taverne

Please check the document version of this publication:

- A submitted manuscript is the version of the article upon submission and before peer-review. There can be important differences between the submitted version and the official published version of record.

People interested in the research are advised to contact the author for the final version of the publication, or visit the DOI to the publisher's website.

- The final author version and the galley proof are versions of the publication after peer review.

- The final published version features the final layout of the paper including the volume, issue and page numbers.

Link to publication

\footnotetext{
General rights rights.

- You may freely distribute the URL identifying the publication in the public portal. please follow below link for the End User Agreement:

www.umlib.nl/taverne-license

Take down policy

If you believe that this document breaches copyright please contact us at:

repository@maastrichtuniversity.nl

providing details and we will investigate your claim.
}

Copyright and moral rights for the publications made accessible in the public portal are retained by the authors and/or other copyright owners and it is a condition of accessing publications that users recognise and abide by the legal requirements associated with these

- Users may download and print one copy of any publication from the public portal for the purpose of private study or research.

- You may not further distribute the material or use it for any profit-making activity or commercial gain

If the publication is distributed under the terms of Article $25 \mathrm{fa}$ of the Dutch Copyright Act, indicated by the "Taverne" license above, 
CLIMATE CHANGE

\section{Impact of climate change on human and animal health}

\section{CLIMATE change is considered a major} threat to human health and wellbeing, with increasing evidence of it affecting infectious diseases (Dufour and others 2008, Gale and others 2009b, Semenza and Menne 2009). But how large is this threat? Will many diseases respond to climate change or only a few? Will as many recede as spread? Is it possible that the most significant diseases in health or economic terms could be resilient to climate change, such that its overall influence on our health and wellbeing could be of relatively minor importance? To answer these questions, we need to assess our disease future realistically, taking into consideration the effects of climate change, the other forces that drive infections, and also possible mitigation measures. Accordingly, the knowledge base for human and animal infectious diseases, particularly a repeatable methodology to predict the effect of climate change on pathogens, needs expansion.

A recently funded multinational project aims to address this knowledge deficit using epidemiological, climatic and risk assessment methods to estimate how a subset of pathogens will change in Europe under various scenarios of future climate change. Many projects have sought to examine the scientific literature for evidence of climate drivers of specific pathogens using top-down approaches (Dufour and others 2008, Gale and others 2009a, b); however, in this new project we have been developing an easily repeatable, bottom-up approach, which allows the examination of many pathogens using multiple steps.

First, the project aims to identify diseases of highest impact, which are influenced by climate, and hence may be susceptible to climate change effects. This involves examining a large number of human and animal pathogens to separate those of very low importance from those of possible societal importance. This will be based initially upon whether they have known pathogenic effects in humans, domestic or companion animals, and using the 'H-index' measure of scientific research impact to characterise the interest in them within the scientific community in terms of the number of papers published and the number of times they have been cited. The pathogens of possible importance will then be run through a risk framework using criteria identified from previous published works to produce a shortlist of highimportance pathogens. The climate and environmental sensitivities of the pathogens in the shortlist and their emerging and zoonotic status will thereafter be ascertained using automated search mechanisms of bibliographic software to identify relevant texts. Manual checking of the literature will then seek actual evidence of climate links including the nature of climate drivers and strength of evidence surrounding them.

Secondly, to assess how future climate will affect shortlisted pathogens, state-ofthe-art climate change forecasts for the target region, such as the EU FP6 ENSEMBLES regional climate models, will be used. These will focus on time-slices between 2020 and 2070, with uncertainty estimated from the probabilistic distribution of likely projected climates. Statistical and mathematical modelling methods will then be developed to predict climate change's effects on chosen pathogens, including estimations of their future distribution, incidence or severity. Pathogen selection criteria will include those with an availability of information, particularly on known climate/environmental sensitivities (such as temperature or soil moisture).

As well as considering the effects of climate change on disease, the project seeks to assess the likely response of stakeholders, decision-makers, and other end-users to the threat from future climate and environmental change. This assessment will also consider non-climate drivers of disease that may influence pathogen emergence, either alone or while also being affected by climate change. These include factors such as flooding and saline water incursion in low-lying areas, education levels, economic resources, access to healthcare and social cohesion. More specifically, this part of the project aims to evaluate the capacity for societal response of different stakeholders, and management options available to mitigate the health effects of climate change. These will be gauged using a participatory process using a Delphi questionnaire approach complemented with focus groups to discuss awareness of problems, readiness to respond, precautionary measures and possible barriers to response.

Further, a range of consistent, coherent and multiform scenarios for changes in infectious disease risk in Europe will be developed, which will include the role of possible trends in relevant non-climatic factors (such as demographics and trade).
This scenario development process will involve dialogue with and input from, for example, policymakers, policy advisers, non-governmental organisations, and scientists. Scenarios will be checked for their assumptions and internal consistency using expert opinion and published information. Following this, an assessment or visualisation of our possible disease future will be undertaken by integrating how future climate will affect shortlisted pathogens and our potential societal response to that threat in terms of possible measures of adaptation and mitigation.

We would be interested to hear of pathogens that practitioners believe may be changing in distribution or prevalence, so that any potential effects of changes in climate as a driver might be investigated.

K. M. McIntyre, C. Setzkorn, M. Baylis, Liverpool University Climate and Infectious Diseases of Animals (LUCINDA) Group, School of Veterinary Science, University of Liverpool, Leahurst Campus, Neston, Cheshire CH64 7TE e-mail: k.m.mcintyre@liv.ac.uk A. Waret-Szkuta, UR AGIRs CIRAD, TA C-22/E, Campus International de Baillarguet, 34398 Montpellier cedex 05, France

C. Caminade, A. P. Morse, Department of Geography, School of Environmental Sciences, Roxby Building, University of Liverpool, Liverpool L697ZT

\section{S-A. Akin, M. Huynen, P. Martens,} International Center for Integrated Assessment and Sustainable Development (ICIS), Maastricht University, PO Box 616, 6200 MD Maastricht, The Netherlands

S. Morand, Institut des Sciences de l'Evolution, CNRS, IRD, Université Montpellier 2, CC065, 34095 Montpellier cedex 05, France

\section{References}

DUFOUR, B., MOUTOU, F., HATTENBERGER, A. M. \& RODHAIN, F. (2008) Global change: impact, mangement, risk approach and health measures - the case of Europe. Revue Scientifique et Technique - Office International des Epizooties 27, 541-550

GALE, P., BROUWER, A., RAMNIAL, V., KELLY, L., KOSMIDER, R., FOOKS, A. R. \& SNARY, E. L. (2009a) Assessing the impact of climate change on vector-borne viruses in the $\mathrm{EU}$ through the elicitation of expert opinion. Epidemiology and Infection 138, 214-225

GALE, P., DREW, T., PHIPPS, L. P., DAVID, G. \& WOOLDRIDGE, M. (2009b) The effect of climate change on the occurrence and prevalence of livestock diseases in Great Britain: a review. Journal of Applied Microbiology 106, 1409-1423

SEMENZA, J. C. \& MENNE, B. (2009) Climate change and infectious diseases in Europe. Lancet Infectious Diseases 9, 365-375 